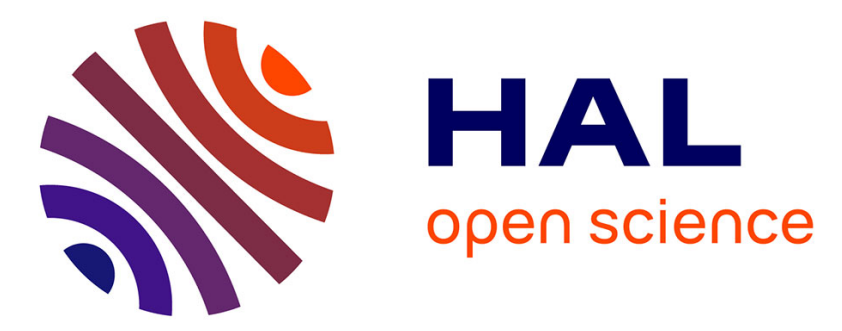

\title{
The inclusive business model revisited: An "extended resource-based theory" (re)definition built on the investigation of three diversified inclusive enterprises in France
}

\author{
Jérémy Tantely Ranjatoelina
}

\section{To cite this version:}

Jérémy Tantely Ranjatoelina. The inclusive business model revisited: An "extended resource-based theory" (re)definition built on the investigation of three diversified inclusive enterprises in France. Strategic Change, 2018, 27 (6), pp.587-597. 10.1002/jsc.2241 . hal-01987078

\section{HAL Id: hal-01987078 https://hal.science/hal-01987078}

Submitted on 21 Jan 2019

HAL is a multi-disciplinary open access archive for the deposit and dissemination of scientific research documents, whether they are published or not. The documents may come from teaching and research institutions in France or abroad, or from public or private research centers.
L'archive ouverte pluridisciplinaire HAL, est destinée au dépôt et à la diffusion de documents scientifiques de niveau recherche, publiés ou non, émanant des établissements d'enseignement et de recherche français ou étrangers, des laboratoires publics ou privés. 


\title{
The inclusive business model revisited:
}

\section{An 'extended resource-based theory' (re)definition built on the investigation of three diversified inclusive enterprises in France ${ }^{1}$.}

\author{
À paraître en 2018 dans le numéro spécial «Sustainable business models » de la revue Strategic Change (volume 27) \\ Merci de ne pas diffuser. \\ Jérémy Tantely RANJATOELINA \\ LEM-CNRS (UMR 9221), Lille, France \\ INSCAE-BRAIN and ISCAM, Antananarivo, Madagasikara
}

The inclusive business model concerns organizations whose strategic intent is to include in their value creation predominantly, people that are being wasted by the dominant practices of actors on the market, due to a presumption of negative performance.

\section{Key points:}

Inclusive business models have been initially defined by the United Nations Development Programme (UNDP).

The 'extended resource based theory' proposes a new typology of resources, which includes the "wasted" resource notion.

The strategic intent is being seen as a main component of the business model and plays an interface role.

Inclusive enterprises predominantly employ people who are excluded from the workplace.

Inclusive business models intentionally include "wasted-by-the-employment-market" human resources predominantly, as "wasted-human-resources-based" business models.

The suggested definition of the inclusive business model is extended to any form of organization fighting against social exclusion and it specifies that the included vulnerable people must be the majority among the human resources.

Through the 'extended resource-based theory' prism, inclusive organizations have both alternative perception and intention towards wasted human resources and inclusive business models realize this alternative intent.

This renewed view of the inclusive business model could facilitate its appropriation and application by both practitioners and researchers and both in developed and in developing countries.

\footnotetext{
${ }^{1}$ JEL classification codes: L31, M10, M12, M14, M51, O15, O35.

The author is grateful towards the following actors for their contributions to this research: the Fondation Agir Contre l'Exclusion (FACE), the Association des Paralysés de France (APF) and the Chambre Régionale de l'Économie Sociale et Solidaire (CRESS) Hauts-de-France; as well as the research team for « strategy, organization and entrepreneurship » of the « organizations performance analysis » department of the LEM and the BRAIN research team of INSCAE; the Editor in Chief of the review and the Guest Editor of the Special Issue; finally, the author is thankful towards the seven anonymous reviewers who revised the paper prior to the conferences during which it has been presented and the reviewer who revised it prior to its publication.
} 


\section{The inclusive business model revisited: An 'extended resource-based theory' (re)definition built on the investigation of three diversified inclusive enterprises in France.}

\section{Introduction}

Inclusive business models are viewed to be addressed generally, by multinational companies, at the 'base of the pyramid' (BOP) markets in the context of developing countries (Prahalad and Hammond, 2002; Prahalad, 2004; Simanis and Hart, 2008; London et al., 2010; Thompson and MacMillan, 2010; George et al., 2012; Halme et al., 2012; Reficco and Màrquez, 2012; Yunus et al. 2012). In general, the notion of "inclusive business" seems to emphasize "the core principle that organizations can and do, engage in social innovation activities to connect disenfranchised individuals and communities with opportunities that foster social and economic growth. In doing so, inclusive growth diminishes trade-offs between growth and inequality because the poor become enfranchised as customers, employees, owners, suppliers, and community members" (George et al., 2012: 661-662). More precisely, the "inclusive business model" is defined by the UNDP «Growing Inclusive Markets » initiative within the following words: "Inclusive business models include the poor on the demand side as clients and customers, and on the supply side as employees, producers and business owners at various points in the value chain. They build bridges between business and the poor for mutual benefit" (UNDP, 2008: 2). This consideration of the people living in poverty seems to drive social innovation within the private sector around the world. It also implies a large diversity of actors, which are federated by UNDP 'Business Call to Action' program (UNDP, 2008, 2010, 2014). Furthermore, the inclusive business model seems to have an empirical resonance with the core activities of every (social and 
classic) enterprise — including developed countries ones — which deliberately employs people who are in a situation of social exclusion in the majority of its human resources. In France, the field of inclusive social enterprises - mainly analyzed in European research within the EMES ${ }^{2}$ network 'work integration social enterprise' (WISE) prism (Borzaga and Defourny, 2001; Nyssens, 2007; Defourny and Nyssens, 2010; Gianfaldoni and Morand, 2015) — is particularly institutionalized. In this context, inclusive social enterprises are particularly regulated and categorized upon a specific categorization of exclusion situations. The different kinds of considered WISEs — by the EMES network related research, namely the structure d'insertion par l'activité économique (SIAE) cf. Borgaza and Defourny (2001); Gianfaldoni and Morand, (2015) — do employ indeed, in a large majority, people who have been unemployed for a long period (two years and more). However, some inclusive-social-enterprise models seem to be unconsidered (or just simply forgotten) by the WISEs' French taxonomy: the entreprise adaptée $(\mathrm{EA})^{3}$ and the établissement et service d'aide par le travail (ESAT) ${ }^{4}$. In these two organization forms, workers in a situation of disability represent more than 80 percent of the global human resources. We advocate that an exploration of both and respectively EA and ESAT models, as the currently recognized WISEs (namely, the SIAE) and as the inclusive (classic) enterprises, should enrich the inclusive business model understanding, definition, and conceptualization. We argue that the (recent) 'extended resource-based theory' (Warnier et al. 2013; Fréry et al., 2015) sheds new theoretical insights on the highlighting of the social inclusion processes (or work integration, or employment) of "negatively-perceived" human resources, by an enterprise. Warnier et al. (2013) suggest a new typology of resources —including

\footnotetext{
${ }^{2}$ The EMES network is research network focused on social enterprises and the social economy. It takes root in a research project called "Emergence of social enterprises in Europe" (1996-1999) and ordered by the DirectorateGeneral Research of the European Commission (http://emes.net/)

3 adapted enterprise

${ }^{4}$ protected sheltered workshop
} 
strategic, ordinary and "negatively perceived" (in terms of performance), resources-, based on the subjective and intersubjective perception by respectively actors and markets. They took as an example for such a "negatively-perceived" —or "wasted" (Morrow, 1957) - human resource (on the employment market) included by a performing (classic) enterprise: the Danish Specialisterne company - currently operating in 11 countries - which develops the work integration of people with Asperger syndrome. This illustration shows that "negatively perceived" "resources can be the basis of new business models when an entrepreneur creates new services (new uses) for them, leading to unsuspected performance" (Warnier et al., 2013: 1374). Fréry et al. (2015) highlight the specificity of business models based on (massive) ordinary resources. In this paper, we investigate within a similar approach the defining characteristics of business models that are built upon (and in favor of) "wasted" (human) resources. In this way, this communication seeks to answer to the following research question: How can we (re)define what an inclusive business model is? We investigate empirically three inclusive enterprises: Vitamine T, APF Entreprises, and Ethik Investment. The paper consists of four parts. The first one presents a literature review of the 'extended resource-based theory' and our business model framework. The second one explains our research design. The third part details the findings about the inclusive business models in France. Finally, in the fourth part, we (re)define and discuss the characteristics of an inclusive business model. 


\section{The inclusive business model within the 'extended resource-based theory'}

The 'extended resource-based theory' and the business model

Following Weppe et al. (2012; 2013), Warnier et al. (2013) extend the resource-based theory by suggesting on the one hand, a new typology of resources including "strategic" ones, "ordinary" ones, and "negatively-perceived"—or "junk"— resources (Table 1).

$===$ Insert here Table $1==$

On the other hand, they propose a representation of the process by which, a creative entrepreneur who identifies a new use, valorizes an under-evaluated resource on the market (Figure 1).

$===$ Insert here Figure $1===$

They insist on the subjective and intersubjective perception in terms of performance, which constitutes the basis of this typology and its categorization, by actors and markets, respectively. In their discussion, they evoke the potential of this extended resource-based theory to analyze organizations that deliberately employ people (as human resources) that are excluded from the workplace.

Furthermore, this extension on resources consideration "raises new questions, echoing the recent work on resource management (Sirmon et al., 2007, 2010) and business models from a resource point-of-view (Demil and Lecocq, 2010)" (Warnier et al., 2013: 1375). The recent development of research works on the 'extended resource-based theory' tends to confirm this echo. On the one hand, Fréry et al. (2015) compare 
business models focused on strategic resources, with business models focused on ordinary resources. They show how ordinary resource-based business models are changing the established rules in many industries through an Internet collaborative platform. On the other hand, Ranjatoelina and Zaoual (2016) highlight the resources' inherent orchestration-capability (Sirmon et al., 2011) in the deliberate inclusion of "wasted resources" (Morrow, 1957).

The inclusion of "wasted human resources"

Warnier et al. (2013) define as a "junk" resource, "a resource overlooked or ignored by firms (i.e. not highly valuated on the market), generally perceived as negative in terms of performance, i.e. with an expected level of productivity lower to its cost (acquisition or development). Such a resource is considered as a source of costs or as destroying value by the firm that possesses it" (p.1371). Ranjatoelina and Zaoual (2016) explore the inclusion of these "negatively-perceived" human resources — oriented by the French public service for employment due to their "low-employability" - in a famous WISE. They demonstrate the implication of six key resources and competences, occurring at every strategic level of the organization, in the orchestration-capability developed by this inclusive social enterprise (Table 2).

$===$ Insert here Table $2===$

Moreover, in reference to J.J. Morrow's advocacy for black American workers' inclusion in southern US enterprises, published in 1957 in the Harvard Business Review, Ranjatoelina and Zaoual (2016) suggest to replace the terms "junk resource" by "wasted resource", especially and obviously in the case of human resources. History shows us indeed, that the human resources concerned by Morrow's article, considered 
as negative at this time, in this space, are now ordinary ones. At the same time, in another space or cultural area the same resource shouldn't necessarily be perceived as "negative" — as Morrow shows us in its comparison between Southern and Northern US for example-. In this way, Ranjatoelina and Zaoual's (2016) reference to Morrow reveals the dynamical character of perception and its dependency to cultural areas.

In an 'extended resource-based theory' perspective, as Fréry et al. (2015) define the platform business model as an ordinary resource-based one, we argue that the inclusive business model corresponds to "wasted" resource-based business model. Nevertheless, this deliberated focalization on "wasted resource" and the distinctive nuances between various existing kinds of inclusive enterprises (social or classic inter alia) tend to suggest the necessary development of a specific business model framework.

\section{Building the 'SI-RCOV framework' of business model}

Inspired by Martinet and Payaud's $(2008 ; 2010)$ strategic-management model for CSR ${ }^{5}$ BOP - including: strategic intent; formula and generic strategy; clients and markets; offer system; value network; strategic competences and resources (trad. by the author) — and C.K. Prahalad's work — and particularly his last publication: "This shift in emphasis forces us to move from a product centric approach to a focus on business model innovation, of which the product is but a subset" (Prahalad, 2012: 11)— our conceptual business model framework suggests to combine the Demil and Lecocq (2010; 2015) 'RCOV framework' with Itami and Nishino (2010) business model definition: " $a$ business model is composed of two elements, a business system and a profit model [...]. A firm's profit model is a model of its strategic intent to achieve various kinds of differentiation from its competitors (by product or price, etc.), while its business system is a system designed to realize that strategic intent" (Itami and Nishino,

\footnotetext{
${ }^{5}$ Corporate Societal Responsibility
} 
2010: 364). We argue that the mobilization of the "strategic intent" concept (Hamel and Prahalad, 1989) (and accessorily intentionally-related notions) appears here obvious, in order to characterize and to essentialize the variety of existing inclusive enterprises in a unique definition and a unique conceptualization. Moreover, our empirical position tends to enhance the conceptual suggestion of the (extended) 'SI-RCOV framework' (Figure 2) - SI-RCOV for: Strategic Intent; Resources and Competences; internal and external Organization; Value propositions - in order to frame our exploration of existing inclusive business models.

\section{Research Design}

\section{Methodology and data}

This research is rooted in a four-year (2013-2016) doctoral research, whose last three years (oct. 2013 to sept. 2016) have been carried out in collaboration ${ }^{6}$ with the Fondation Agir Contre l'Exclusion (FACE) ${ }^{7}$, the Association des Paralysés de France $(\mathrm{APF})^{8}$ and the Chambre Régionale de l'Economie Sociale et Solidaire Hauts-deFrance (CRESS) ${ }^{9}$. Our methodology is composed of four stages of investigation (Table 3).

\footnotetext{
${ }^{6}$ Within a French public-private conventionalized $\mathrm{PhD}$ called a $\mathrm{PhD}-$ CIFRE, for "Industrial Convention for a Research Formation", as a researcher-consultant

7'Act against exclusion foundation', FACE is the main network of companies committed in favor of the Corporate Societal Responsibility (CSR) in France, with more than 5.000 company-members, federated and acting through nearly forty (non-profit) clubs of companies, social enterprises, and a « sheltering » foundation recognized as public utility. FACE seeks to engage companies for social and sustainable actions in favour of local communities.

${ }^{8}$ 'Physical disability France association', APF is the second NGO/association in France in terms of numbers. Recognized as public utility, its portfolio of activities is very diversified and based on supporting people with disability throughout life.

${ }^{9}$ Hauts-de-France 'regional chamber of social and solitary economy', CRESS leads the network, in France, of social and solitary economy actors (ESS) in regions. It is an NGO, recognized as public utility, benefiting of a delegation from the public services in order to represent the State and to report the exchanges in regions through the National Council of the CRESS (CNCRESS).
} 
Although this research is abductive, we try to represent linearly our qualitative investigation design (Figure 2) to build a theoretical definition from a multiple cases study: "the process of building theory from case study research is a strikingly iterative one. While an investigator may focus on one part of the process at a time, the process itself involves constant iteration backward and forward between steps. For example, an investigator may move from cross-case comparison, back to redefinition of the research question, and out the field to gather evidence on an additional case" (Eisenhardt, 1989: 546).

$===$ Insert here Figure 3==

During the second and third, years we principally collected observation and interaction notes about the three cases, two meetings and 21 online videos ${ }^{10}$ about one of them, and seven exploratory interviews with relevant actors. During the fourth year, we realized a seven confirmatory-interviews sequence with General Managers and Directors of our three cases.

\section{The multiple-cases study}

The majority of research works on BOP seems generally to be oriented to developing countries. Still, in France the inclusive business model currently knows a real empirical interest regarding CSR organizational networks like FACE (cf. IMS-Entreprendre pour la cité, 2013a, 2013b). FACE federates a more than 5.000-companies network, 
committed to act through a social-enterprises portfolio, against all forms and situations of exclusion, discrimination and poverty, in France and abroad (Brussels, Belgium; Rio de Janeiro, Brazil; Bizerte, Tunisia).

The singularity of our action-research partnership and the quest after exhaustivity had led us to retain three characteristical but non representative diversified enterprises Vitamine T, APF Entreprises, and Ethik Investment - out of four established inclusive business models - the ESAT business model, the EA one, SIAE one, and classicinclusive company business model - in France. In this perspective, we voluntarily excluded "self-inclusive" business model(s), in other words the case in which a person in a situation of exclusion or vulnerability creates its own enterprise.

\section{Findings: three diversified inclusive enterprises in France}

\section{Vitamine T}

Founded in 1978, Vitamine $T$ is one of the most famous inclusive social enterprises in France - one of the leaders of the work integration sector, and of the social and solitary economy - achieving a turnover of 40 million euros and a consolidated net result of 1.6 million euros in 2013. Its unique shareholder is the non-profit association called Vitamine $T$. The entrepreneurial and strategic intent of its business models is to employ temporary people in a low-income and a long unemployment situation, within a 4 to 24 months' work-integration contract, to take them out of their individual social exclusion. Pôle Emploi — the French Employment Public service - relieves to people unemployed for more than two years, an approval attesting this situation and representing the pass 
for the incorporation in a work-integration social enterprise (SIAE). These targeted human resources represent 70 percent of Vitamine T's total employees -1.788 on 2.524 in 2013 - These people participate to the value creation as they simultaneously ensure their competences by learning a job within one of the 12 activities of Vitamine T's portfolio (Table 4).

$===$ Insert here Table $4===$

To manage its social performance, the key indicators for Vitamine $T$ and for the "temporary work integration sector" $" 11$, is the post-inclusion "dynamic pursuit rate" 12 of the included human resources. It implies the constraint for every temporary-inclusive enterprise to maintain the stability of the economic activity, despite the constant renewal of the majority of the human resources. This organization appears specific to temporaryinclusive business models. It suggests as well that the work-integration sector contributes, at the macro level, to fluidize the job market by actualizing the skills of wasted human resources. To maintain both economic and social performance, the business portfolio and its dynamics from its foundation -in other words the organizational entrepreneurial capability—, appears to be a Vitamine $T$ differentiating advantage. Indeed, since 1978, Vitamine $T$ has launched (alone or in partnership) eighteen activities, has acquired four activities, and has known five cessations and three resales (Table 5).

$===$ Insert here Table $5===$

\footnotetext{
11 «insertion par l'activité économique »

12 «taux de sorties dynamiques»
} 
These dynamics and the six key resources and competences -identified by Ranjatoelina and Zaoual (2016) — , give to Vitamine $T$ the ability to include its target human resources in activities, which are in coherence with the job market needs. Indeed, to reach the social objectives — in terms of 'dynamic pursuit rate' - the permanent portfolio adaptation to activities and industries, which recruit today and tomorrow, appears within this form of work integration to be a key success factor.

\section{APF Entreprises}

APF Entreprises is the first group of inclusive social enterprises in the French adapted sector. It sustainably employs 3.200 people in situation of disability, on about 3.900 total employees. APF Entreprises manages and assists the business development of its 49 social enterprises, 24 ESAT and 25 EA, and its unique shareholder is the APF NGO. Since 2005 in France, every company having more than 20 employees has the legal obligation to employ disabled workers, up to 6 percent of its global workforce. Up to half of that quota, companies can buy goods and/or services from EA or ESAT, purchases to the adapted sector being considered under law as indirect employment of disabled workers. In an EA as in an ESAT, more than 80 percent of the workforce is (individually) in a situation of disability. These two kinds of inclusive social enterprise share the same objective but differ on their respective targeted human resources and on their respective (internal and external) organization. Indeed, the situation of disability is institutionally recognized by the RQTH ${ }^{13}$, delivered by the $\mathrm{CDAPH}^{14}$ of the $\mathrm{MDPH}^{15}$. The CDAPH also statutes on the level of disability of the person and orientates towards ESAT those who the commission believes that they would reach the requirements of the

\footnotetext{
${ }^{13}$ Reconnaissance de la qualité de travailleur en situation de handicap : "Recognition of disabled worker"

${ }^{14}$ Commission des droits et de l'autonomie des personnes en situation de handicap : "Rights and autonomy commission of people with disability"

${ }^{15}$ Maison départementale des personnes en situation de handicap : "Departmental house of disabled people"
} 
job market with difficultly. Because, while the EA is a "traditional" social enterprise with traditional employment contracts-, the ESAT is a hybrid organization combining inclusive-social-enterprise activities, cares and eventually medical services, in which the targeted human resource is considered as worker but not as employee. In an ESAT, even if disabled workers received a remuneration in exchange of their work contribution to the value creation, they sign a "user contract" - governed by the Code for Social Action and Families and not the Labor Code, and for a period of one or two years renewable and generally renewed - and constitute in this way, the principal beneficiaries of the model. Although field actors consider EA and ESAT as a single sector - the adapted (and sheltered) sector-, the nuances between ESAT and EA suggest that each one corresponds to a specific business model. It is the reason why, after the strategic intent of APF Entreprises — which is common to APF's EA and ESAT — we present in this section, as one, the general results of the ESAT and EA business systems, insisting on their distinguishing nuances.

Property of a non-profit organization, in addition to being inclusive, the entrepreneurial and strategic intent of APF Entreprises is necessarily social (as Vitamine T's one). Indeed, APF is one of the main associations in France with 25.377 members, 13.572 employees, about 25.000 volunteers, and the main in the domain of social inclusion of people in a situation of disability. The APF associative project for the period 2012-2017 is entitled: "Move the Lines! For an Inclusive Society"16 . In this way, the social mission of APF Entreprises — which in reality is a department of APF headquarter - is to include on a long term perspective, workers in a situation of disability through one of the 24 ESAT or 25 EA, and their respective activities. APF Entreprises strategic intent has been recast with the arrival of the new management team in 2014. This year indeed, APF's board recruited a new General Manager, who nominated a new APF Entreprises

\footnotetext{
16 « Bouger les lignes! Pour une Société Inclusive»
} 
Manager and his new team. The intent of this new management comforts the belonging of EA and ESAT to the social economy and tends to incorporate a collaborative spirit, both vertical (inter-levels) and horizontal (intra-levels, and with competitors). These new collaborations, between subsidiaries (EA and ESAT), between APF Entreprises department and some subsidiaries, and also with competitors, sustain the group's development and lead to new synergies, ensuring both economic and social activities. One of the economic objectives included in the new strategic intent is also to reduce the dependency to subsidy revenues, to anticipate its probable reduction. Within more than three decades of existence, the year 2015 is the first with a positive net result, showing that this actualized strategic intent of APF is already bearing fruit for APF Entreprises.

Recognized disabled workers compose the large majority -80 percent minimum — of both models' human resources, in other words they have a RQTH. In France, the unemployment rate of workers in a situation of disability is more than twice higher -22 percent — than the general unemployment of the total population - 10,2 percent—, and the average period of unemployment is longer by 206 days for disabled people -799 days - than the entire population -593 days $-{ }^{17}$. These numbers and facts highlight the "wasted" character of workers with disability as a human resource on the employment market. Generally, due to CDAPH's perception, the level of disability is higher among ESAT's beneficiaries than among EA's employees, making them to appear as even more "wasted". To include their target human resources, the six key resources and competences can be found here with some nuances. On the one hand, APF Entreprises' governance is hybrid, the group develops and sustains partnerships and collaboration, and every EA or ESAT manages its own activity portfolio. On the

\footnotetext{
17 « Tableau de bord national. Emploi et chômage des personnes handicapées. France entière. Bilan du premier trimestre 2016 » ('National Scoreboard. Employment and unemployment of people with disability. Whole France. Results of the first 2016 quarter'). AGEFIPH Publications, ํ2016-2, 2016, june 23th, 13p., available online : https://www.agefiph.fr/Actus-Publications/Publications-et-etudes
} 
other hand, APF Entreprises competence consists more in operations, sales and business than in entrepreneurship; the social and professional individualized coaching — which correspond to EA's practices - can be extended to cares and eventually medicals in ESAT; and, APF's APF Formation department acts like an internal training body, but not reduced to APF Entreprises. APF Formation seems more to emphasize the actualization of supervisors' competences rather than disabled workers' competences.

During the last three decades, APF Entreprises' organization has experienced a pendulum phenomenon from a centralized model to a territorial one and vice versa (verbatim). Since 2014, every EA and ESAT manages and develops its business portfolio activities according to market opportunities of their action perimeter. In terms of business, APF Entreprises segments its activities in eight poles of skills: communication products and services, administrative services, environment, logistic, electronic and electrical, mechanics and carpentry, other BtoB services, and $A P F$ Entreprises' products. Long-term market relations also lead to the development of innovative activities, business systems, and value proposals co-constructed on the specific local needs of customers become partners. For example, after analyzing — with $K P M G$ - the next 5 to 10 years needs of its customers and prospects, APF's EA of Illkrich ${ }^{18}$ is now the only company, in Eastern-France, which develops electronic and electrical production on the same site. The specialization has allowed this EA to penetrate the market of radiofrequency and connected objects, thanks to a recent technological investment of 500,000 euro, and by creating four jobs. Its products not exhaustively include: cables used by Alstom to equip French regional trains, receivers of digital terrestrial television, remote controls, programming suitcases for home automation systems, trackers for scooters, and GPS maps for fixing on trolley

\footnotetext{
${ }^{18}$ near to Strasbourg in the Bas-Rhin French department
} 
supermarkets. Another example could be the APF's EA of Amiens ${ }^{19}$. Supported by Air France, the EA has invented a semi-automated process of reconditioning airheadphones, unique in the world. In 2016, Air France is the first customer for this business with a volume of 30,000 to 50,000 air-headphones from a total of 80,000 reconditioned headphones per day.

EA and ESAT create simultaneously value propositions of three different natures, addressed to three kinds of stakeholders, at three levels. At a micro-level, the first value proposition of the EA or ESAT is an employment one to the individuals who are wasted on the employment market - it is particularly true in the ESAT where the disabled worker is considered as a beneficiary or a client- - At a meso-level, the nature of the second value proposition is consisted by products and services to clients and customers. The eight poles of skills and the two previous examples suggest the diversity, the variety of the $A P F$ Entreprises' value propositions to markets. And at a macro-level, EA and ESAT assume a general interest mission that could be seen as value proposition for the State and all the society. In this perspective, although APF Entreprises wishes to reduce its dependency to subsidies, revenues from Public services can be seen as the fair retribution of ESAT and EA' societal contribution.

\section{Ethik Investment}

Ethik Investment is an inclusive (classic) company. A part of 50 percent of its total human resources is in a situation of disability. It permanently employs about 80 persons and federates an approximatively 300 consultants-contributors network, and achieved a turnover of 5 million euros in 2013. The group operates in three BtoC activities with the brand "Dans le Noir?": restaurants (present in six countries: France, United-Kingdom, United States, Spain, Russia, and Kenya), wellness centers and spas, and shops. The

\footnotetext{
${ }^{19}$ in the Somme French department
} 
basement of the concept is for employees with reduced visual capacity to take care of customers in a (total or partial) dark environment. Ethik Connection aggregates three BtoB activities: Ethik event, event and sensitization (exported in six countries: UnitedKingdom, Poland, Thailand, Saudi Arabia, Switzerland, and Spain); Ethik Management, consulting in coaching and training; and Ethik Image, consulting in strategy, communication and creation.

Founded in 2003 by two associates (now three in total), among which one is in a situation of disability (blindness), Ethik Investment's entrepreneurial and strategic intent is defined by its General Manager as "doing business differently" and "change the point of view of society". Indeed, while one company out of five does not employ any disabled worker, and while the disabled workers' direct employment rate is 3,3 percent (when the law requires 6 percent since 2005), half of Ehtik Investment's human resources, and a third of its associates are in a situation of disability. Ethik Investment' subsidiaries simultaneously make for-profit business and include recognized disabled workers. This intent differentiates the group particularly from every marketcompetitors, from the adapted sector, appearing to be the basis of the group's social innovation.

Half of the global human resources are recognized as disabled workers. Indeed, they individually have a RQTH as more-than-80-per-cent EA's employees. In term of disability, blind or partially sighted persons compose the majority of Ethik Investments's employees. To include its disabled workers, the group seems to have developed key resources and competences. Governance appears to be (classic but) inclusive. Indeed, groups of companies that have a blind person among their associates and for General Manager are very rare. The partnerships and managers' managerial social capital, sustain the development of co-innovations, principally in the field of 
events and training, as we'll see after. The "Dans le Noir?" trademark, its experiential concept, and the inclusive-activities business portfolio of the group appear to be sources of synergies and even innovations. With the experience acquired through the restaurants and the event activity, a careful thought around the wellness sector has led to the creation of a first spa in Paris and a second franchised one in Bordeaux, in 2011. For centuries, elsewhere in the world and mostly in Asia, the wellness sector has been particularly inclusive in favor of blind and partially sighted persons thanks to their natural skills in touching and handling. So, very quickly, the added value on client experience brought by blind persons' competences and situation — blindness becomes here an asset because clients who could be reluctant to undress in sight of a person in a full ability to see are more inclined to do it in front of a blind person-, is recognized by the observers - the spa is ranked second best spa of Paris by the French magazine L'Express - and by competitors as a real competitive advantage (verbatim). Training and apprenticeship of disabled employees are strategic considering the low qualification of two third of them -66 percent of disabled workers left school before finishing high school—. Ethik Investment focuses on this thematic in various ways. For example, the spa activity acts like a sectorial training body by assuming disable persons' training within a certificate of professional competence in esthetics developed with the Espace Beauté Thalgo International and the access for people with a reduced visual capacity to ISIPCA's professional license in analysis and application and its professional master degree in sensory formulation and evaluation-. In the same way in other sectors, the group co-develops training and certificates with academic partners: the first master in management initially developed for blind students, and then for all disabled students was launched within Kedge Business School in 2011; the technician certificate in insurance of the École Supérieure d'Assurances was made accessible for all disabled 
students in 2012; idem in 2013 with IRIS school's technician certificate in IT service to organizations, and with Le CNAM's professional license degree in analysis and design of information and decision systems, and its engineering degree in information systems. The job and managerial coaching of disabled employees and services providers appears to be adapted and focused on their abilities and competences. Associated to the event activity's resources and competences it reverses positively the public's perception about employing disabled workers.

As we have just seen, the internal and external organization of Ethik Investment's activities is based on disabled workers' abilities and competences. Indeed, the organization is internally oriented to improve their competences on activities, and externally oriented to move the regard of the society through the business models' value propositions.

The value propositions of the group are addressed in a way to three stakeholders. The first kind is a goods and/or services' proposition to clients and customers. These value propositions are related to each activity or they can follow some synergies, like for example, the "spackage" which includes for two persons: a duo massage and a mixed steam room session at the wellness center, and then a head-to-head meal at the restaurant. The second kind of value propositions is (direct or indirect) an employment proposition to disabled employees and services providers. Functions and contracts of disabled workers are classic ones. The third kind is a shared value proposition to society. However, no group revenue comes from public subsidies (as opposed to social enterprises benefiting from "employment aid" ${ }^{20}$ ). The financial independence allows to sustain the development of innovative inclusive business models and projects. For example, since 2014, through Ethik Connection's partnership with the Fondation Malakoff Médéric Handicap, the group has also piloted a project to improve

\footnotetext{
20 « aides aux postes »
} 
employment's access and retention for workers with autism in France and more particularly workers with Asperger autism.

\section{Defining and discussing the inclusive business models by its strategic intent}

\section{Discussing the results}

In this paper we sustain that inclusive business models concern not only the developing countries and not only organizations involved against poverty. Our 'in-partnership' action-research led to the selection, retention, and exploration of three cases of established enterprises —Vitamine T, APF Entreprises, and Ethik Investment - which include four major inclusive business models in France: the social business model which includes predominantly and in a long-term perspective recognized disabled workers who would difficultly reach job-market expectations (that is the ESAT); the social business model which includes predominantly and in a long-term perspective recognized disabled workers (that is the EA); the social business model which temporary predominantly includes workers unemployed for a long period (that is the SIAE); the business model which includes, in a classic way, for half, recognized disabled workers (that is the disability-inclusive company).

This exploration highlights distinctions and nuances between the categories ("segments"?) of people targeted as "beneficiaries" by these various kinds of enterprises. It shows that in developed countries, existing major inclusive enterprises are more focused on excluded workers' employment than directly on poverty reduction. In this way, the inclusive business models appear to be addressed to the poor people but 
also to other categories of disenfranchised people (Halme et al., 2012) that we holistically consider to be (individually) in a situation of social exclusion or vulnerability. Indeed, poverty can be seen as a form of economic exclusion —leading in the quasi-totality of the cases to a situation of social exclusion-. Our results confirm that on the job market all those excluded workers' have a common characteristic, they are "wasted" human resources. In other words, their job applications are constantly rejected because of the presumption of negative performance that recruiters have about them.

Our results, especially Ethik Investment's ones, also allow us to discuss the six key resources and competences to include wasted human resources (Ranjatoelina and Zaoual, 2016). First, the governance of the Ethik Investment group is not hybrid but its entrepreneurial and strategic intent is inclusive. Its social innovation lies in the exclusive business character of its revenues. This suggests replacing the "hybrid governance" by an inclusive entrepreneurial and strategic governance (maybe social), as the first key resource and competence of an inclusive business model. Partnerships and leadership's "managerial social capital", the inclusive-activities portfolio, some entrepreneurial and business skills, are found in the three cases. Therefore, these three key resources and competence of inclusive business model remain unchanged. Concerning the fifth key resource and competence, according to the results of Ethik Investment's case we understand that we should not only focus on the training of human resources initially being neglected by the market, but also on the awareness of the people and society about human resources that are being "wasted" nowadays. Finally, the sixth key resource and competence of an inclusive business model can also be amended, following our results: job coaching and individualized management based on initially-wasted-human-resources' abilities, competencies, and projections. 
The SI-RCOV business model framework, elaborated and proposed in this research, extends the RCOV model (Demil and Lecocq, 2010, 2015). The results reveal the methodological potential of the SI-RCOV framework to frame not only social and/or inclusive enterprises' business models, but also every static or dynamic business model(s) analysis.

Those results lead us to suggest a (re)definition of what an inclusive business model is.

\section{Defining what an inclusive business model is}

UNDP's definition of the inclusive business model is centered on poor people's inclusion. However, our results highlight that inclusive business models in developed countries are mostly focused on excluded workers' employment. The common points revealed by our three cases make the inclusive business models correspond to the business models based on a majority of wasted human resources. This focalization in favor of wasted human resources can be explained as an inclusive strategic intent. So, to define conceptually what an inclusive business model is, our theoretical ground and the results of our multi-cases study lead us to suggest the following definition: "An Inclusive Business Model is a business model characterized by an inclusive entrepreneurial and strategic intent in favor of human resources that are being 'wasted' by the traditional markets, due to their situation of poverty and/or vulnerability. The business system(s) of such a business model realizes this differentiating inclusive intent by including these people as the predominant human resources of the value creation (employees, producers/providers, entrepreneurs) of one activity or more, developed and organized within a coherent adaptation with their abilities, competences, and projections". This definition emphasizes a holistic perspective and refers to several scientific streams and concepts in 
strategic management. Articulating two levels - the strategic intent of the model and its realization-, it contributes to Itami and Nishino's (2010) business model definition and conception. Indeed, following Itami and Nishino (2010) we insist on the central role of (entrepreneurial and) strategic intent in the business model. Moreover, this centrality of strategic intent and its direction in favor of people excluded from the markets, directly refer to C.K. Prahalad's work (Hamel and Prahalad; 1989; Prahalad and Hart, 2002; Prahalad and Hammond, 2002; Prahalad, 2004, 2012). Defining theoretically the inclusive business model by its strategic intent in favor of wasted human resources also contributes to the 'extended resource-based theory' stream (Warnier et al., 2013; Fréry et al., 2015; Ranjatoelina and Zaoual, 2016), which constitutes the first research focused on wasted resource-based business models. As we introduced it, our findings confirm the interest of this new prism - its theoretical anchorage and articulation - to renew strategic management's view upon social business models (Yunus et al., 2010) and inclusive social enterprises (Borzaga and Defourny, 2001; Nyssens, 2007; Defourny and Nyssens, 2010; Gianfaldoni and Morand, 2015). Indeed, defining a business model by both its model of entrepreneurial and strategic intent, and its business system(s) appears particularly relevant to the exploration, the analysis and the development of business models which differentiate themselves by their social aim. In this way, this research tends to comfort the relevance of considering within the business model prism, organizations and activities that deliberately create "not-only-economic" value (Hart and Milstein, 2003; London et al. 2010; Porter and Kramer, 2011), such as hybrid organizations (Hockerts, 2015). 


\section{Implications and propositions}

Regarding the inclusive business model within the 'extended resource-based theory', this research reveals and suggests interesting implications, which lead to the formulation of four research propositions.

Proposition 1: the use of a main strategic management theory should facilitate practitioners' appropriation equally in developing and developed countries. Indeed, the complete framework — including its theoretical definition and articulation — suggested in this research is likely to support the development of inclusive enterprises at the international level.

Proposition 2: this new theoretical anchorage should also facilitate the development of strategic-management researchers' interest for inclusive enterprises —and especially social ones-. For instance, the 'extended resource-based theory' sheds new light on WISEs (Borzaga and Defourny, 2001; Nyssens, 2007; Defourny and Nyssens, 2010; Gianfaldoni and Morand, 2015) models analysis (Ranjatoelina and Zaoual, 2016).

Even if the choice of the geographical investigation field could appear quite surprising, we argue that this empirical context points out some insightful implications for strategy and for society.

On the one hand, the 'extended resource-based theory' explains how an entrepreneur with an alternative strategic intent for a resource, reaches to create a performing organization. Nevertheless, it does not evoke the imitation and/or replication of a 'generic' business model, which leads to the emergence of a new sector, a new industry. Two of our three cases have been founded more than 35 years ago and move towards particularly regulated sectors and environments with strong norms —it explains why they are characteristical but non representative of their respective sectors-. 
Proposition 3: there are one dominant and one alternative view towards wasted resources. The explored sectors - the work-integration sector and the adapted sectordo not share the dominant perception and intent about wasted human resources on the job market. The organizations of these sectors do not perceive their predominant human resources negatively.

Proposition 4: the 'extended resource-based theory' would be amended by a theoretical loop. As leaders of their respective sectors, these two cases should contribute to enrich the 'extended resource-based theory' (Figure 1) with a recursive phenomenon which highlights new sectors emergence — from the performing business model to a marketperceptions' actualization-, corresponding to the collective response of the range of actors sharing the same (alternative) view and strategic intent about an under-evaluated resource.

On the other hand, the very institutionalized context in France suggests an abundance of experimented initiatives - contingent certainly but- contributing, in terms of learning, to the global uprising of inclusive business models and to the reinvention of the global economic system (Porter and Kramer, 2011). Indeed, inclusive generally rimes with universal. By analyzing this context, this research puts a highlight on three particularly inspiring enterprises for every actor aspiring to singularly do business differently.

\section{Conclusion}

This research focuses on a topic remaining insufficiently observed in the literature: the business model of enterprises, which deliberately and predominantly include wasted human resources on the employment market. It is based on the exploration of three 
diversified inclusive enterprises in France -Vitamine T, APF Entreprises, and Ethik Investment - , highlighting the nuances and distinctions, and the common characteristics of their respective business models. This highlighting suggests to (re)define the inclusive business model by its strategic intent in favor of wasted human resources. Managerial and societal implications of this research are of interest to many stakeholders (for example institutional actors, social entrepreneurs and entrepreneurs, social economy's managers, consultants, researchers and teachers). Its theoretical contributions strengthen the extended resource-based theory. However, the exclusive investigation of cases from a developed country suggests the relevance to extend this research by exploring inclusive business models in the context of a developing country. Such an exploration will allow us to overcome the limitations of this research by consolidating our design and studying the possible determinism of context about inclusive business models' configuration.

\section{References}

Borzaga, C., Defourny, J. (2001). The emergence of social enterprise London and New York, Routledge, edition 2004.

Defourny, J., Nyssens, M. (2010). Conceptions of Social Enterprise and Social Entrepreneurship in Europe and the United States: Convergences and Divergences. Journal of Social Entrepreneurship, vol. 1, n 1, pp. 32-53.

Demil, B., Lecocq, X. (2010). Business Model Evolution: In Search of Dynamic Consistency. Long Range Planning vol. 43, pp. 227-249.

Demil B., Lecocq X., (2015). Crafting an Innovative Business model in an established company: The role of Artifacts in Baden-Fuller, C., Mangematin, V. (ed.). Business Models and Modelling, Advances in Strategic Management, vol. 33, Emerald Group Publishing Limited, pp.31-58.

Eisenhardt, K. M. (1989). Building Theories from Case Study Research. Academy of Management Review, vol. 14, n4, pp. 532-550.

Fréry, F., Lecocq, X., Warnier, V. (2015). Competing with ordinary resources. MIT Sloan Management Review, Spring, pp. 69-77.

George, G., McGahan, A.M., Prabhu, J. (2012). Innovation for Inclusive Growth: Towards a Theoretical Framework and a Research Agenda", Journal of Management Studies, vol. 49, n²4, pp.661-683. 
Gianfaldoni, P., Morand, P.-H. (2015). Incentives, Procurement and Regulation of Work Integration Social Enterprises in France: old ideas for new firms? Annals of Public and Cooperative Economics, vol. 86, n², pp. 199-219.

Hamel, G., Prahalad, C.K. (1989). Strategic Intent. To revitalize corporate performance, we need a whole new model of strategy. Harvard Business Review, may-june, pp. 6376.

Halme, M., Lindeman, S., Linna, P. (2012). Innovation for Inclusive Business: Intrapreneurial Bricolage in Multination Corporations. Journal of Management Studies, vol. 49, n 4 , pp. 743-784.

Hart, S.L., Milstein, M.B. (2003). Creating Sustainable Value. Academy of Management Executive, vol. 17, n², pp. 56-67.

Hockerts, K. (2015). How Hybrid Organizations Turn Antagonistic Assets into Complementarities. California Management Review, vol. 57, n³, pp. 83-106

IMS-Entreprendre pour la cite (2013a). The need for enhanced public support for Inclusive Business Models. IMS, sept. 2013, available online: http://fr.calameo.com/read/00113083765021a8b04a4

IMS-Entreprendre pour la cite (2013b). Toolkit on inclusive Business Models: A compilation of key tools and reference documents. IMS, sept. 2013, available online: http://fr.calameo.com/read/001130837d4fdfec8f060

Itami, H., Nishino, K. (2010). Killing Two Birds with One Stone: Profit for Now and Learning for the Future. Long Range Planning, vol. 43, pp. 364-369.

London, T., Anupindi, R., Sheth, S., (2010). Creating mutual value: Lessons from ventures serving base of the pyramid producers. Journal of Business Research, vol. 63, $\mathrm{n}^{\circ} 6$, pp. 582-594.

Morrow, J. J. (1957). American Negroes - a Wasted Resource. Harvard Business Review, vol. 35, jan./feb. 1957, pp. 65-74.

Martinet, A.-C., Payaud, M.A. (2008). Formes de RSE et entreprises sociales. Revue Française de Gestion 2008/11, vol. 180, p. 199-214.

Martinet, A.-C., Payaud, M.A. (2010). La stratégie BOP à l'épreuve des pauvretés. Revue Française de Gestion 2010/9, vol. 208-209, p. 63-81

Nyssens, M. (2007). Social Enterprise. At the crossroads of market, public policies, and civil society. ed. Routledge 2006, 335p.

Prahalad, C.K., Hart, S. L. (2002). The Fortune at the Bottom of the Pyramid. Strategy+Business, issue 26, first quarter 2002, pp. 1-14.

Prahalad, C.K., Hammond, A. (2002). Serving the World's Poor, Profitably. Harvard Business Review, sept. 2002, R0209C, pp. 4-11.

Prahalad, C.K. (2004). The fortune at the bottom of the pyramid: Eradicating poverty with profits. Wharton Business Publishing, Philadelphia.

Prahalad, C.K. (2012). Bottom of the pyramid as a Source of Breakthrough Innovations", Journal of Product Innovation Management, vol. 29, n¹, p. 6-12.

Porter, M.E., Kramer, M.R. (2011). Creating Shared Value. How to reinvent Capitalism - and unleash a wave of innovation and growth. Harvard Business Review, jan./feb 2011, R1101C, pp.1-17.

Ranjatoelina, J.T., Zaoual, A.-R. (2016). Inclure des Ressources Délaissées. Le groupe Vitamine T, un spécialiste de l'insertion. Revue Française de Gestion, vol. 42, n²55, pp. 121-138.

Reficco, E., Màrquez, P. (2012). Inclusive Networks for Building BOP Markets. Business \& Society, vol. 51, n³, pp. 512-554. 
Simanis, E., Hart, S.L. (2008). The Base of the Pyramid Protocol: Toward Next Generation BOP Strategies", second edition, 2008, 51p., available on www.bopprotocol.org

Sirmon, D.G., Hitt, M.A., Ireland, R.D. (2007). Managing firm resources in dynamic environments to create value: looking inside the black box. Academy of Management Review, vol. 32, n¹, pp. 273-292.

Sirmon, D.G., Hitt, M.A., Ireland, R.D., Gilbert, B.A. (2011). Resource orchestration to create competitive advantage breadth, depth, and life cycle effects", Journal of Management, vol. 37, $\mathrm{n}^{\circ}$ 5, pp. 1390-1412.

Thompson, J.D., MacMillan, I. (2010). Business Models: Creating new markets and Societal Wealth. Long Range Planning, vol. 43, pp. 291-307.

UNDP, (2008). Creating Value for All: Strategies for Doing Business with the Poor. Growing Inclusive Markets Initiative, july 2008, United Nations Development Programme, 180p., available online: http://growinginclusivemarkets.org/media/gimlaunch/Report_2008/GIM\%20Report $\% 20$ Final\%20August $\% 202008 . p d f$

UNDP, (2010). Brokering Inclusive Business Models. Private Sector Division, Partnerships Bureau, United Nations Development Programme, 75p., available online: http://www.undp.org/content/dam/undp/library/corporate/Partnerships/Private $\% 20$ Secto r/Brokering\%20Inclusive \%20Business\%20Models.pdf

UNDP, (2014). Breaking Through: Inclusive Business and the Business Call to Action today. Mapping challenges, Progress and the Way Ahead. Business Call to Action, sept. 2014, United Nations Development Programme, 68p., available online: http://www.businesscalltoaction.org/wp-

content/uploads/2014/09/BCtAImpactReport_BreakingThrough.pdf

Warnier, V., Weppe, X., Lecocq, X. (2013). Extending Resource-Based Theory: Considering strategic, ordinary and junk resources. Management Decision, vol. 51, $\mathrm{n}^{\circ} 7$, pp. 1359-1379.

Weppe, X., Warnier, V., Lecocq, X. Fréry, F. (2012). Quand les postulats d'une théorie induisent de mauvaises pratiques. La 'théorie des ressources' selon J. B. Barney. Revue Française de Gestion, 2012/9-10 n²28-229, p. 253-268.

Weppe, X., Warnier, V., Lecocq, X. (2013). Ressources stratégiques, ressources ordinaires et ressources négatives. Pour une reconnaissance de l'ensemble du spectre des ressources. Revue Française de Gestion, n²34, p. 43-63.

Yunus, M., Moingeon, B., Lehmann-Ortega, L. (2010). Building Social Business Models: Lessons from the Grameen Experience. Long Range Planning, vol. 43, pp. 308-325.

Yunus, M., Sibieude, T., Lesueur, E. (2012). Social Business and big business: innovative, promising solution to overcome poverty? Field Actions Science Report, Special Issue 4, janv. 2012, pp. 68-74. 
Figure 1: The extended resource-based theory

Industry level

Intersubjectivity

- Strategic Resource

- Ordinary Resource

- Junk Resource

Pricing process
Entrepreneur level

Subjectivity

Evaluation of the resource

Decision process
Organization level

Actualisation

$\Rightarrow$

Actions on the resource

(business model)

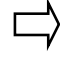

Level of performanc

Figure 2: The SI-RCOV framework of the business model

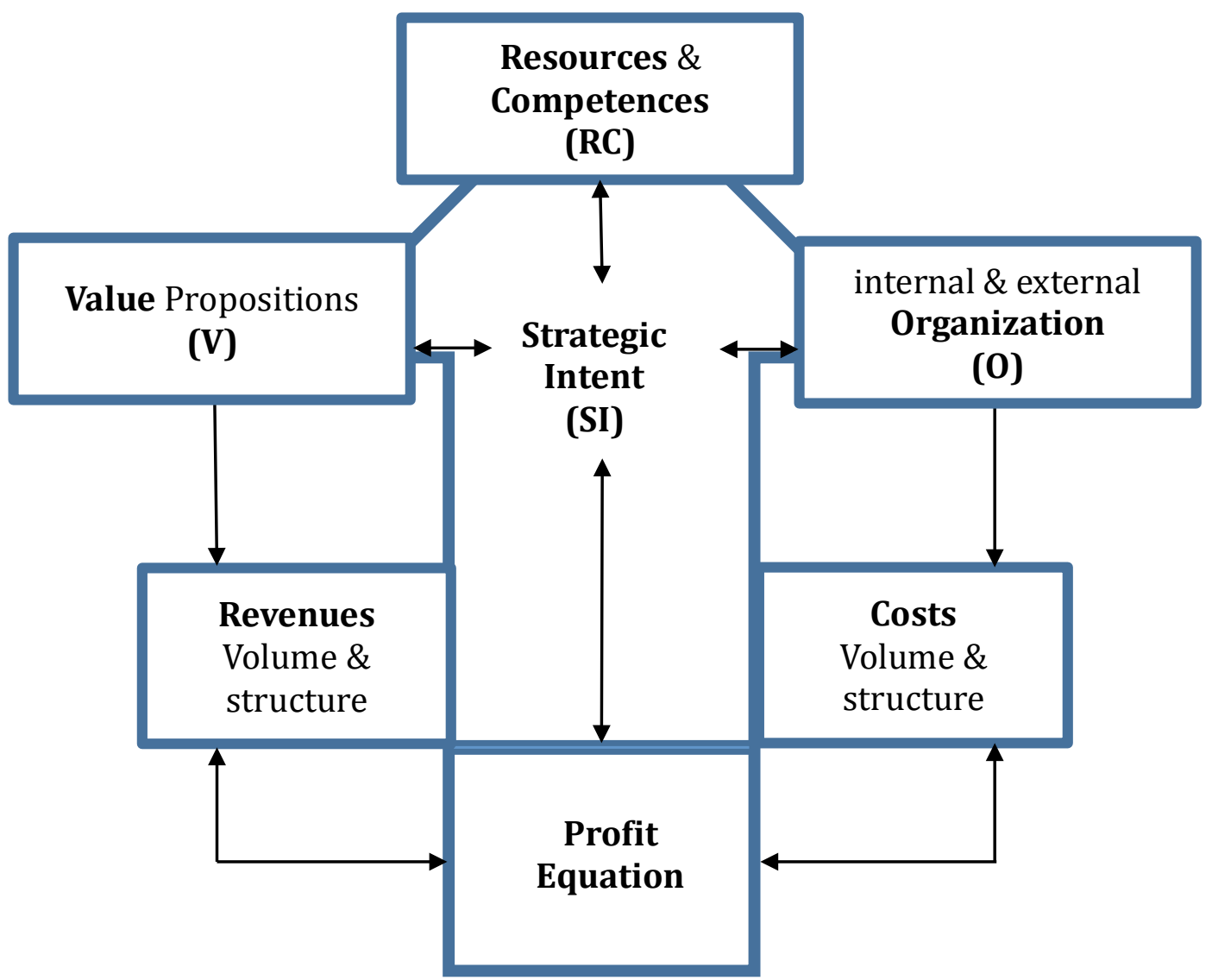

Source: the author 
Figure 3: A qualitative research design

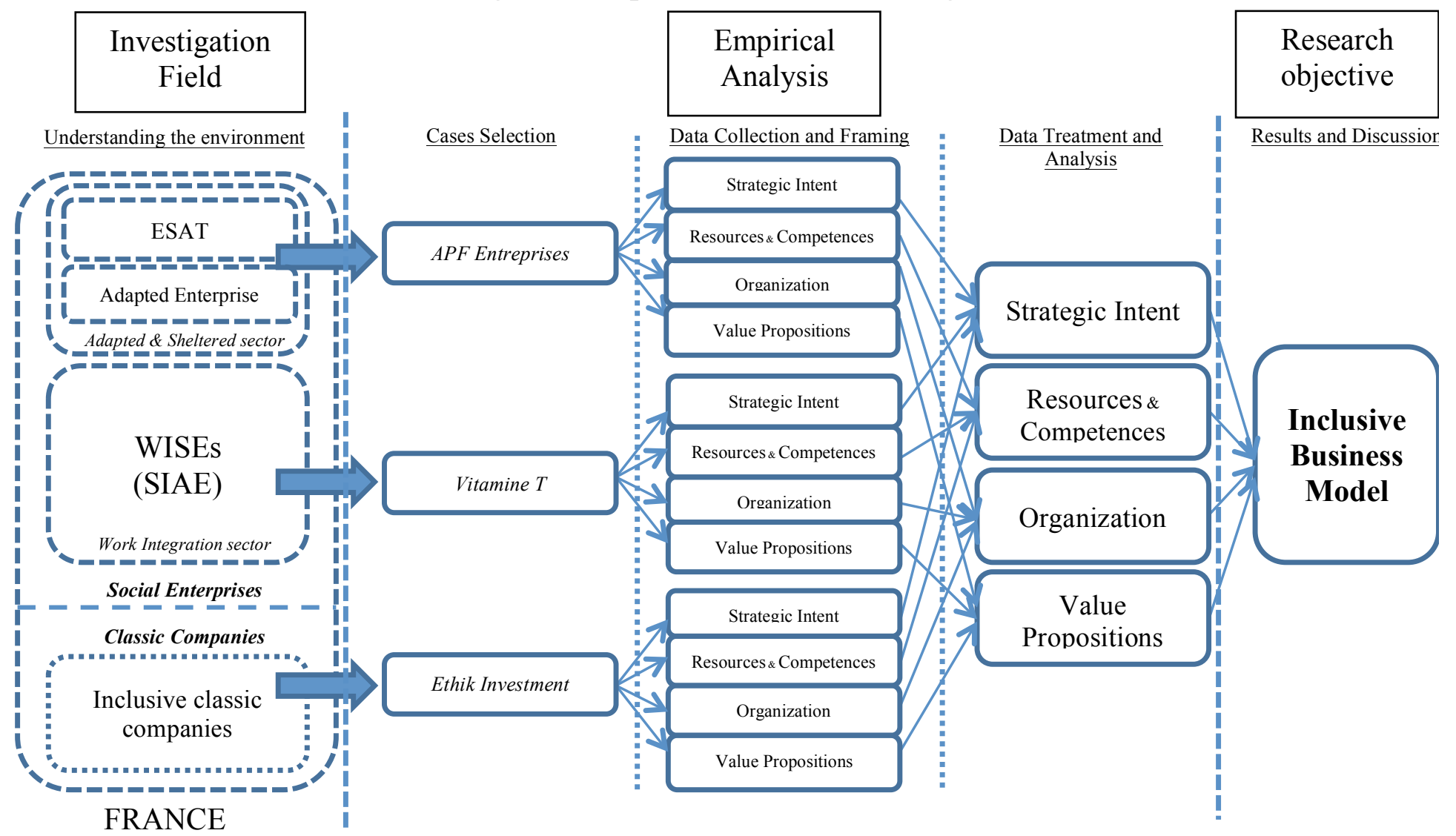

Source: the author

Table 1: Three types of resources

\begin{tabular}{|c|c|}
\hline $\begin{array}{l}\text { Strategic } \\
\text { resource }\end{array}$ & $\begin{array}{l}\text { "A rare resource on the market, generally perceived as positive in terms of } \\
\text { performance, i.e. with an expected level of productivity that is greater than its } \\
\text { cost (acquisition or development). Such a resource is considered a potential } \\
\text { source of rents" }\end{array}$ \\
\hline $\begin{array}{l}\text { Ordinary } \\
\text { resource }\end{array}$ & $\begin{array}{l}\text { "A common resource on the market, generally perceived as neutral in terms } \\
\text { of performance, i.e. with an expected level of productivity equivalent to its } \\
\text { cost (acquisition or development). Such a resource is considered, at best, as } \\
\text { ensuring competitive parity" }\end{array}$ \\
\hline $\begin{array}{c}\text { Junk } \\
\text { resource }\end{array}$ & $\begin{array}{l}\text { "A resource overlooked or ignored by firms (i.e. not highly valuated on the } \\
\text { market), generally perceived as negative in terms of performance, i.e. with an } \\
\text { expected level of productivity lower than its cost (acquisition or development). } \\
\text { Such a resource is considered as a source of costs or as destroying value by } \\
\text { the firm that possesses it" }\end{array}$ \\
\hline
\end{tabular}

Source: Warnier et al. (2013: 1368-1371) 
Table 2: The key resources and competences implicated in 'wasted' resource inclusion

\begin{tabular}{|c|c|}
\hline Key Resources and Competences & Strategic level \\
\hline A hybrid governance & \multirow[b]{2}{*}{ Corporate } \\
\hline $\begin{array}{l}\text { Partnerships whereby leadership's « managerial social capital» and } \\
\text { external engagements seem to play a spreading and a non neglectable } \\
\text { legitimation role }\end{array}$ & \\
\hline $\begin{array}{l}\text { A diversified activities-portfolio of inclusive business which generate } \\
\text { synergies }\end{array}$ & \multirow{2}{*}{ Business } \\
\hline $\begin{array}{l}\text { An entrepreneurial capability based on the permanent actualization } \\
\text { principle of the inclusive activities-portfolio }\end{array}$ & \\
\hline $\begin{array}{l}\text { A social and professional individualized coaching in which an } \\
\text { included and permanent employees' association allows a significant } \\
\text { improvement of « wasted » human resource's 'employability' }\end{array}$ & \multirow[t]{2}{*}{ Functional } \\
\hline A Training body which proposes adapted training contents & \\
\hline
\end{tabular}

Source: Ranjatoelina and Zaoual (2016: 135)

Table 3: A four-year investigation

\begin{tabular}{|c|c|c|c|c|c|c|c|c|c|c|c|c|c|c|c|c|}
\hline & \multirow{2}{*}{\multicolumn{4}{|c|}{2013}} & \multirow{2}{*}{\multicolumn{4}{|c|}{2014}} & \multirow{2}{*}{\multicolumn{4}{|c|}{2015}} & \multirow{2}{*}{\multicolumn{4}{|c|}{2016}} \\
\hline & & & & & & & & & & & & & & & & \\
\hline & $\mathrm{T} 1$ & $\mathrm{~T} 2$ & $\mathrm{~T} 3$ & $\mathrm{~T} 4$ & $\mathrm{~T} 1$ & $\mathrm{~T} 2$ & T3 & $\mathrm{T} 4$ & $\mathrm{~T} 1$ & $\mathrm{~T} 2$ & $\mathrm{~T} 3$ & T4 & $\mathrm{T} 1$ & $\mathrm{~T} 2$ & $\mathrm{~T} 3$ & $\mathrm{~T} 4$ \\
\hline \multicolumn{17}{|l|}{ Partnership elaboration } \\
\hline \multicolumn{17}{|l|}{ Definition of Research Question } \\
\hline \multicolumn{17}{|l|}{ Literature review } \\
\hline \multicolumn{17}{|l|}{ Empirical integration and presence } \\
\hline \multicolumn{17}{|l|}{ Exploration and Data collecting } \\
\hline \multicolumn{17}{|l|}{ Cases identification and selection } \\
\hline \multicolumn{17}{|l|}{ Analysis } \\
\hline \multicolumn{17}{|l|}{ Writing } \\
\hline Discussion of intermediary productions & & & & & & & & & & & & & & & & \\
\hline
\end{tabular}

Source: the author 
Table 4: Vitamine T's business portfolio

\begin{tabular}{|c|c|c|}
\hline Subsidiaries & Activities & Capital Repartition \\
\hline $\begin{array}{l}\text { La Ferme des } \\
\text { Jésuites }\end{array}$ & \multirow{2}{*}{$\begin{array}{c}\text { Gardening, maintenance of green } \\
\text { spaces }\end{array}$} & Vitamine $T(100 \%)$ \\
\hline $\begin{array}{c}\text { Les Serres des } \\
\text { Prés }\end{array}$ & & Vitamine $T(100 \%)$ \\
\hline Inser'Croix & $\begin{array}{l}\text { Pallets recycling, eco-friendly cleaning } \\
\text { vehicles }\end{array}$ & Vitamine $T(100 \%)$ \\
\hline Soluval & Out-of-service vehicles recycling & $\begin{array}{l}\text { Vitamine T(78\%) } \\
\text { Macif }(22 \%)\end{array}$ \\
\hline Envie 2 e Nord & $\begin{array}{l}\text { Electric, electronic, and home } \\
\text { appliance recycling }\end{array}$ & $\begin{array}{l}\text { Vitamine } T(83 \%) \\
\text { Van Gansewinkel }(17 \%)\end{array}$ \\
\hline Envie Nord & $\begin{array}{l}\text { Household appliances, furniture and } \\
\text { second-hand items renovation and sale }\end{array}$ & Vitamine $T(100 \%)$ \\
\hline Janus & Temporary job placement & $\begin{array}{l}\text { Vitamine } T(66 \%) \\
\text { Adecco }(34 \%)\end{array}$ \\
\hline Médiapole & Social mediation & Vitamine $T(100 \%)$ \\
\hline Mobilille & Urban mobility services & Vitamine $T(100 \%)$ \\
\hline Solutis & Cleaning services & Vitamine $T(100 \%)$ \\
\hline Vitavert & Urban cleaning & Vitamine $T(100 \%)$ \\
\hline$I F V T$ & Certified training body & Vitamine $T(100 \%)$ \\
\hline
\end{tabular}

Source: secondary data 
Table 5: Vitamine T's development: more than 35 years of social entrepreneurship

\begin{tabular}{|c|c|}
\hline $\begin{array}{l}\text { Internal } \\
\text { Development }\end{array}$ & $\begin{array}{l}\text { 1978: Réabat Bâtiment } \\
\text { 1980: Janus } \\
\text { 1983: Vit'Imprim } \\
\text { 1986: Art } \\
\text { 1987: Inter } \\
\text { 1992: Envie Hauts de France } \\
\text { 1996: Vitacopier } \\
\text { 1998: Le Bec à Plumes } \\
\text { 1999: Vitavert } \\
\text { 2002: Mediapole } \\
\text { 2002: La Ferme des Jésuites } \\
\text { 2011: Mobilille } \\
\text { 2013: IFVT }\end{array}$ \\
\hline $\begin{array}{l}\text { Development in } \\
\text { partnership }\end{array}$ & $\begin{array}{l}\text { 1993: creation of Cleanauto with Norauto } \\
\text { 1998: minoritary participation of Adia France (Groupe Adecco) in Janus } \\
\text { 2006: creation of Envie } 2^{E} \text { Nord with Van Gansewinkel } \\
\text { 2009: creation of Soluval with La Macif } \\
\text { 2010: creation of La Part du Pain (Lille) with Paul (Groupe Holder) }\end{array}$ \\
\hline $\begin{array}{l}\text { External } \\
\text { development } \\
\text { (acquisition) }\end{array}$ & $\begin{array}{l}\text { 1990: Les Serres des Près } \\
\text { 2008: Envie Picardie by Envie Nord } \\
\text { 2009: L'Ucie Intérim by Janus } \\
\text { 2014: Inser'Croix }\end{array}$ \\
\hline $\begin{array}{l}\text { New business } \\
\text { units }\end{array}$ & $\begin{array}{l}\text { 2010: Solutis at Paris-La Défense } \\
\text { 2011: La Part du Pain at Ronchin } \\
\text { 2014: Le Grenier d'Envie at Seclin }\end{array}$ \\
\hline Name change & $\begin{array}{l}\text { 2000: Art becomes Solutis } \\
\text { 2000: Vit'Imprim becomes Vit'Sérigraphie } \\
\text { 2007: Réabat Bâtiment becomes Solubât } \\
\text { 2008: Envie Hauts de France becomes Envie Nord }\end{array}$ \\
\hline Cession & $\begin{array}{l}\text { 2005: Vitacopier } \\
\text { 2005: Vit'Sérigraphie } \\
\text { 2013: La Part du Pain (Lille) }\end{array}$ \\
\hline Cessation & $\begin{array}{l}\text { 2001: Cleanauto } \\
\text { 2007: Inter } \\
\text { 2012: La Part du Pain (Ronchin) } \\
\text { 2012: Le Bec à Plumes } \\
\text { 2013: Solubât }\end{array}$ \\
\hline
\end{tabular}

Source: secondary data 


\section{Biographical note}

Jérémy Tantely RANJATOELINA is a researcher, a consultant and a lecturer. His French-written-PhD thesis title is: Inclusive business models: an action research study on fighting against social exclusion through employment in France (2017). During his $\mathrm{PhD}$, he has worked as a CSR consultant-researcher at the Fondation Agir Contre l'Exclusion (FACE), in partnership with the Association des Paralysés de France (APF) and the Chambre Régionale de l'Économie Sociale et Solidaire (CRESS) of the Northern region of France. He has lectured at IAE Lille school of management of the University of Lille and at the business school of Amiens. He is currently pursuing his research at both laboratories LEM-CNRS (UMR 9221) in France and BRAIN (INSCAE). $\mathrm{He}$ is also permanent lecturer at INSCAE university school of management and parttime lecturer at $I S C A M$ business school, both located in Antananarivo, Madagasikara.

Correspondence to:

Jérémy Tantely RANJATOELINA

INSCAE, Bureau 605

Immeuble INSCAE 67ha, B.P. 946, Antananarivo 101, Madagasikara

Fax: + 261.20.22.308.95

Email: jranjatoelina@inscae.mg 